\title{
Peran Pendidikan Kewirausahaan Dan Love Of Money Terhadap Intensi Berwirausaha Pada Mahasiswa Akuntansi
}

\author{
${ }^{1 *}$ Agni Astungkara, ${ }^{2}$ Rochmi Widayanti \\ ${ }^{1,2}$ Fakultas Ekonomi, Akuntansi, Universitas Islam Batik Surakarta, Indonesia \\ *Email korenpondensi: agniastungkara@gmail.com
}

\begin{abstract}
The pattern of accounting education at the university level is often direct the student to fulfill positions at established companies or institutions. The competencies held by accounting graduates should also be directed to support a country's economy through its role in the field of entrepreneurship. It cannot be denied, entrepreneurship is one of the pillars of the country's economy. Therefore entrepreneurial behavior must always be encouraged, one of them through entrepreneurship education. This study will examine the role of entrepreneurship education and the Love of Money towards the intention to entrepreneurship in accounting students. The results showed that entrepreneurship education independently has not been able to encourage intentions for entrepreneurship, but students with high levels of Love of Money have an influence on entrepreneurial intentions. The sample in this study were 70 accounting students at one of the private university in Surakarta. Through this research the university is expected to be able to encourage accounting students to become entrepreneurs, as well as to package the patterns of activities to be more effective and efficient.
\end{abstract}

Keywords:accounting student, entrepreneurship, love of money, entrepreneurship education, entrepreneurship intention, love of money.

Saran sitasi: Astungkara, A., \& Widayanti, R. (2020). Peran Pendidikan Kewirausahaan Dan Love Of Money Terhadap Intensi Berwirausaha Pada Mahasiswa Akuntansi. Jurnal Akuntansi dan Pajak, 20 (2), 252-260. doi:http://dx.doi.org/10.29040/jap.v20i2.725

\section{DOI: http://dx.doi.org/10.29040/jap.v20i2.725}

\section{Pendahuluan}

Pendidikan akuntansi pada perguruan tinggi seringkali diarahkan untuk memenuhi kebutuhan perusahaan. Para mahasiswa akuntansi seringkali diarahkan untuk memenuhi posisi yang ada dalam perusahaan atau institusi lainnya. Potensi para mahasiswa akuntansi jarang diarahkan untuk menjadi pelaku wirausaha. Kompetensi yang dimiliki oleh para lulusan akuntansi sesungguhnya dapat dipergunakan untuk menunjang perekonomian negara melalui bidang kewirausahaan. Kompetensi yang dimiliki oleh lulusan akuntansi dapat dimanfaatkan untuk menyelenggarakan laporan keuangan yang berkualitas sehingga meningkatkan nilai tambah unit usaha.

Kemajuan dalam bidang perekonomian dapat ditandai dengan banyaknya produsen-produsen dalam negeri yang dapat mempertahankan eksistensinya, baik di dalam maupun di luar negeri merupakan salah satu tanda kemajuan dalam bidang ekonomi. Tentunya hal ini membutuhkan peran dari berbagai pihak. Pelaku wirausaha, pemerintah dan pembuat regulasi, serta masyarakat memiliki peran yang signifikan dalam kemajuan perekonomian.

Produsen atau wirausahawan yang mampu bertahan tersebut tidak dapat terlepas dari pihak eksternal, seperti pemerintah, investor, dan para pemangku kepentingan lainnya. Produsen baik dalam sektor barang maupun jasa, tentunya tidak hanya mencakup pada produsen dalam skala besar, namun juga mencakup produsen rintisan atau perusahaan-perusahaan rintisan yang sedang berkembang. Para wirausahawan tersebut harus selalu didorong dan didukung agar dapat bertahan dalam arus perekonomian. Baik melalui pasokan modal, kebijakan yang tepat bagi para pelaku usaha, dan kemudahan untuk mengakses informasi yang 


\section{Jurnal Akuntansi dan Pajak, 20(02), 2019, 258}

dapat berguna bagi perkembangan bisnis para wirausahawan.

Dukungan dan dorongan tersebut harus terus dilakukan mengingat, peran wirausahawan sebagai salah satu tiang penyangga perekonomian suatu negara. Tidak hanya berdampak pada individu wirausaha, namun juga dapat memberikan dampak positif yang lebih luas kepada lingkungan bahkan negaranya. Adanya wirausaha ini secara langsung akan menimbulkan kemandirian dalam segi ekonomi dan mengurangi kebergantungan pada pihak lain.

Manfaat yang lebih luas dari adanya wirausaha adalah dengan banyaknya para wirausahawan di suatu negara maka akan banyak lapangan kerja yang terbuka. Kebutuhan akan tenaga kerja akan meningkat seiring dengan meningkatknya jumlah wirausahawan. Hal ini tentu dapat memberikan manfaat yang cukup besar bagi negara dengan jumlah angkatan kerja yang tinggi, seperti yang terjadi pada negara Indonesia. Adanya fenomena bonus demografi di Indonesia dapat menjadi tantangan tersendiri. Apabila bonus demografi ini tidak dimanfaatkan dengan baik maka akan menjadi bumerang tersendiri bagi Indonesia, namun apabila fenomena ini dapat ditangani dengan baik maka bukanlah suatu hal yang mustahil jika Indonesia akan tumbuh menjadi negara maju.

Fakta di lapangan menunjukkan bahwa jumlah wirausaha belum begitu banyak jika dibandigkan dengan jumalah penduduk Indonesia saat ini. Terlebih pada golongan muda. Masih banyak lulusan perguruan tinggi yang lebih memilih untuk bekerja pada perusahaan-perusahaan yang telah mapan dibandingkan dengan lulusan yang memilih untuk berwirausaha. Tidak terkecuali para lulusan dari rumpun ekonomi dan bisnis. Hal ini tentunya perlu dicermati, faktor apa sajakah yang selama ini mempengaruhi para tenaga muda untuk berwirausaha.

Mahasiswa akuntansi merupakan mahasiswa yang mendalami mengenai ilmu akuntansi dan ilmu bisnis lainnya. Lulusan program studi akuntansi ini dianggap setidaknya mampu menyelenggarakan proses keuangan dengan baik. Kemampuan para lulusan akuntansi ini diharapkan mampu menciptakan sebuah bisnis, mengingat mereka sudah banyak terpapar mengenai isu bisnis. Kemampuan yang mereka miliki diharapkan mampu membuat bisnis yang baik. Ilmu yang mereka pelajari akan memberikan kontribusi bagi bisnis mereka. Ketika para lulusan bidang bisnis ini dapat didorong untuk menjadi pelaku wirausaha, maka bukan tidak mungkin mereka akan memberikan kontribusi bagi pertumbuhan ekonomi.

Penelitian sebelumnya menyebutkan bahwa pendidikan kewirausahaan telah lama dipertimbangkan sebagai salah satu instrumen untuk meningkatkan sikap kewirausahaan bagi wirausahawan baru (Liñán, Cohard, dan Cantuche, 2011). Sayangnya masih belum banyak ditemukan cara jitu yang efektif dan efisien untuk meningkatkan minat berwirausaha.

Penelitian yang dilakukan oleh Liñán, Cohard, dan Cantuche (2011) menjelaskan bahwa kontrol pribadi perilaku adalah faktor yang paling relevan dalam menjelaskan kewirausahaan. Penelitian yang dilakukan oleh Zhang, Duysters, dan Cloodt, (2014) menunjukkan bahwa hasil positif atas pendidikan kewirausahaan terhadap intensi berwirausaha, akan tetapi terdapat dampak negatif atas pengaruh paparan atas isu-isu kewirausahaan terhadap intensi untuk berwirausaha. Adanya hasil penelitian yang masih kontradiktif tersebut perlu adanya penelitian yang menjelaskan lebih lanjut terkait peran edukasi kewirausahaan terhadap intensi berwirausaha. Variabel kepribadian belum banyak dipertimbangkan sebagai variabel penunjang intensi untuk berwirausaha. Melalui penelitian ini akan diteliti salah satu cara untuk meningkatkan minat berwirausaha.

Komitemen untuk berwirausaha tidak hanya pada perkataan semata, namun kepribadian juga turut berperan dalam implementasi komitmen untuk berwirausaha. Karakteristik love of money akan diuji dalam penelitian ini untuk dapat mendorong minat dalam berwirausaha. Perpaduan pemilihan karakteristik individu dan edukasi kewirausahaan diharapkan dapat menjadi salah satu cara efektif untuk meningkatkan jumlah wirausaha.

\section{Tinjauan Pustaka \\ Pendidikan Kewirausahaan}

Kewirausahaan bukanlah suatu hal yang asing di Indonesia. Sudah dari beberapa tahun yang lalu pemerintah mendorong masyarakatnya untuk berwirausaha. Kewirausahaan merupakan suatu kebaranian yang dimiliki individu untuk mampu mengubah peluang menjadi kenyataan yang memiliki nilai dengan didasari ide kreatif dan inovatif serta keberanian untuk menanggung risiko (Noersasongko, 2017). Kewirausahaan ini merupakan suatu konsep mengenai produksi barang 


\section{Jurnal Akuntansi dan Pajak, 20(02), 2019, 259}

dan jasa yang dapat disalurkan kepada pasar. Seiring tumbuhnya kewirausahaan maka akan berimbas pada perekonomian suatu negara. Data dari Kementrian Koperasi dan UKM menyebutkan bahwa pada tahun 2017, Usaha Mikro Kecil dan Menengah menyumbangkan sekitar $60 \%$ terhadap Produk Domestik Bruto (PDB), dan sisanya sebesar $40 \%$ merupakan kontribusi usaha dengan skala besar.

Data tersebut menunjukkan bahwa kontribusi terhadap PDB, mayoritas merupakan sumbangsih dari UMKM. Data yang ada tersebut menunjukkan bahwa kewirausahaan memiliki porsi penting untuk menumbuhkan suatu perekonomian. Artikel yang ditulis oleh Acs (2006), menyebutkan bahwa kewirausahaan memberikan dampak positif bagi pertumbuhan ekonomi dengan cara pengusaha menciptakan bisnis baru yang akan berimplikasi dengan adanya pembukaan lapangan kerja, persaingan menjadi intensif dan bakan produktivitas dapat meningkat dengan adanya perubahan tekonologi.

Pemberian informasi kepada masyarakat dan pendampingan mengenai kewirausahaan perlu dilakukan. Pendidikan kewirausahaan telah lama dipertimbangkan sebagai salah satu instrumen untuk meningkatkan sikap kewirausahaan bagi wirausahawan baru (Liñán, Cohard, dan Cantuche, 2011). Peran pendidikan kewirausahaan dapat memberikan pengaruh signifikan terhadap intensi berwirausaha, karena dengan semakin sering seseorang bersinggungan dengan isu kewirausahaan akan meningkatkan minat berwirausaha (Ardiyani dan Kusuma, 2016; Wedayanti dan Giantari, 2016; Wibowo, 2017) . Pendidikan kewirausahaan memiliki peran untuk dapat membentuk pola pikir, sikap, serta perilaku mereka untuk menjadi pelaku wirausaha (Lestari dan Wijaya, 2002)

Kementrian terkait di Indonesia sudah membentuk aturan terkait pendidikan kewirausahaan untuk perguruan tinggi. Salah satu bentuk implementasi dari kebijakan tersebut adalah masuknya mata kuliah kewirausahaan pada sesi kegiatan belajar mengajar.

\section{Love of Money}

Setiap individu dalam upayanya mencapai capaian yang diharapkan membutuhkan motivasi. Motivasi dibutuhkan karena merupakan suatu komponen yang penting, mengingat motivasi meliputi kekuatan, arah dan ketekunan seseorang dalam usahanya untuk dapat meraih tujuan (Robins dan Judge, 2015). Masing-masing memiliki motivasi tersendiri dalam setiap pelaksanaan tugas maupun pekerjaan.. motivasi tersebut dapat berupa motivasi moneter dan motivasi non moneter.

Studi yang dilakukan oleh Bonner dan Sprinkle (2002) menunjukkan bahwa faktor moneter memiliki potensi yang lebih menjanjikan untuk pencapaian tujuan, apabila dibandingkan motivasi dalam bentuk non moneter. Hal tersebut dikuatkan dengan studi yang dilakukan oleh Gagne dan Deci (2005) yang menyatakan bahwa mayoritas orang yang bekerja memiliki motivasi untuk mengumpulkan uang.

Tahun 1992, Thomas Li-Ping Tang mengambangkan skala mengenai tingkat kecintaan seseorang terhadap uang. Tang (1992) mengembangkan skala pengukuran kecintaan terhadap uang tersebut dibagi menjadi enam faktor. Konsep love of money merupakan suatu konsep yang membahas mengenai kecintaan seseorang terhadap uang (Tang, 2008). Adanya skala pengukuran love of money tersebut akan mengukur seberapa tinggi tingkat seseorang dalam mencintai uang dan upaya untuk mendapatkan uang atau materi tersebut. Tingginya indikator love of money seseorang mengindikasikan kecintaan mereka terhadap uang. Bagi individu dengan love of money tinggi menganggap uang adalah sesuatu yang baik, kepemilikan uang adalah suatu bentuk pencapaian prestasi, adanya uang adalah simbol kebebasan, adanya uang adalah salah satu bentuk kepercayaan diri.

\section{Pengembangan Hipotesis}

Menjadi seorang wirausaha bukanlah suatu hal yang asing lagi di Indonesia. Jargon-jargon serta ajakan untuk berwirausaha sudah banyak didengungkan di Indonesia, namun fakta di lapangan menunjukkan masih sedikit jumlah penduduk Indonesia yang mengimplementasikan wacanawacana untuk berwirausaha. Berwirausaha memang bukanlah hal yang mudah, perlu adanya tekad dan keberanian untuk mengambil risiko. Sedikitnya jumlah pelaku wirausaha dapat disebabkan karena salah satunya faktor ketidakmampuan individu untuk mengubah peluang menjadi kenyataan dan diwujudkan dalam bentuk nilai. Ketidakmampuan tersebut dapat dijelaskan dengan faktor tidak adanya faktor kemampuan dan keilmuan untuk mengubah peluang menjadi kenyataan. 


\section{Jurnal Akuntansi dan Pajak, 20(02), 2019, 260}

Program pendampingan kewirausahaan, kompetisi bisnis, dan program kreativitas mahasiswa kewirausahaan telah dilakukan oleh Kemenristekdikti untuk menciptakan para pelaku wirausaha baru. Namun, jumlah pelaku wirausaha di Indonesia masih jauh dari negara maju, jumlah pelaku wirausaha di Indonesia masih berada pada kisaran 3,1\% (Kompas, 2018). Studi yang dilakukan oleh Donckles (1991), dan Zhao, Seibert, dan Hills (2005), mengisyaratkan bahwa pendidikan kewirausahaan penting untuk meningkatkan jumlah pelaku wirausaha.

Penelitian yang dilakukan Zhang, Duysters, dan Cloodt (2014) pada mahasiswa dari universitas di China menunjukkan bukti bahwa dengan adanya pendidikan kewirausahaan dapat memberikan stimulan untuk intensi berwirausaha. Pendidikan kewirausahaan menurut beberapa penelitian terdahulu dapat memberikan dampak positif pada munculnya intensi untuk berwirausaha. Hal tersebut dapat dijelaskan dengan adanya pemberian pendidikan kewirausahaan maka akan terdapat transfer keilmuan terkait ilmu-ilmu kewirausahaan, sehingga para individu tersebut memiliki gambaran atas apa yang seharusnya dilakukan untuk menjadi pelaku wirausaha. Hipotesis pertama yang dapat dirumuskan dari uraian diatas adalah:

$H_{1}$ : Pendidikan kewirausahaan berpengaruh terhadap intensi mahasiswa akuntansi untuk berwirausaha

Satu sisi pada kebudayaan kapitalis menunjukkan bahwa uang menjadi ukuran atas segala sesuatu dan diinginkan hampir semua orang (Coleman, 1992). Tidak dapat dipungkiri, uang telah menjadi kebutuhan dan keinginan bagi mayoritas individu. Uang dibutuhkan untuk dapat memenuhi kebutuhan individu baik kebutuhan jasmani maupun rohani. Gagne dan Deci (2005) menyatakan dalam studinya bahwa hampir semua orang bekerja untuk mencari uang. Hasil penelitian Morton dan Podolny (2002) mengindikasikan bahwa untuk memperoleh materi (uang) seseorang akan berupaya lebih giat dalam menjalankan usahanya.

Individu akan berusaha lebih keras jika hal tersebut dibutuhkan untuk mendapatkan uang. Kepemilikan akan materi, dalam hal ini adalah uang, dianggap sebagai salah satu solusi untuk memecahkan permasalahan hidup. Individu yang berasal dari latar belakang keluarga dengan ekonomi menengah ke bawah, akan lebih susah untuk mencapai posisi puncak keuangan yang mapan.
Individu-individu tersebut harus melalui langkah yang panjang dan berat untuk dapat mencapai posisi keuangan tersebut jika mereka menggunakan jalur karir yang normatif. Adanya kegiatan wirausaha akan memberikan alternatif sebagai lompatanlompatan untuk dapat mencapai posisi puncak keuangan yang mapan.

Individu yang memiliki tingkat kecintaan yang tinggi terhadap uang, dan memiliki aspirasi atas uang akan semakin termotivasi untuk dapat mencapai posisi kepemilikan materi yang mapan. Individu tersebut akan mencari cara tercepat untuk dapat meraih hal tersebut. Menjadi wirausaha adalah cara yang dapat ditempuh ketika ingin meraih materi yang lebih besar. Adanya kesempatan tersebut akan dimanfaatkan oleh individu yang memiliki tingkat love of money tinggi untuk berwirausaha.

Tingkat sensitivitas mahasiswa akuntansi terhadap uang dapat dikatakan lebih tinggi dibandingkan dengan mahasisw program studi lain. Karena mayoritas pembelajaran akuntansi membahas mengenai nilai uang dan pemaksimalan pencapaian nilai ekonomi. Adanya sensitivitas terhadap uang maka mahasiswa akuntansi akan berupaya untuk mencapai nilai ekonomi tertitinggi dalam kehidupannya. Hipotesis kedua yang dapat dirumuskan dari uraian di atas adalah:

$\mathrm{H}_{2}$ : Tingginya tingkat love of money akan berpengaruh terhadap tingginya intensi mahasiswa untuk berwirausaha

Beberapa penelitian terdahulu menunjukkan bahwa pendidikan akuntansi berperan dalam mempengaruhi kognitif seseorang untuk berwirausaha. Pendidikan kewirausahaan yang diberikan kepada mahasiswa akan meningkatkan intensi untuk berwirausaha (Zhao, Seibert, dan Hills, 2005). Ying et al., (2015), menunjukkan bukti bahwa adanya paparan mengenai isu-isu kewirausahaan dapat memberikan dampak negatif terhadap intensi mahasiswa untuk berwira usaha.

Perlu adanya studi lebih lanjut untuk memahami efektivitas peran dari pendidikan kewirausahaan. Faktor internal individu seperti karakteristik atau sikap individu terhadap sesuatu perlu diperhatikan dalam efektivitas peran pendidikan kewirausahaan terhadap intensi berwirausaha. Sikap seseorang terhadap sesuatu dapat menjadi motivasi intrinsik. Seperti sikap sesorang terhadap uang (materi). Individu akan mengerahkan berbagai cara untuk mendapatkan apa yang mereka inginkan. Adanya pendidikan 


\section{Jurnal Akuntansi dan Pajak, 20(02), 2019, 261}

kewirausahaan akan memberikan solusi bagi individu untuk memperoleh penghasilan yang besar. Tingginya kecintaan seseorang terhadap uang akan mendorong seseorang untuk berwirausaha, mengingat dengan berwirausaha individu tersebut akan berpotensi untuk memiliki penghasilan yang besar.Hipotesis ketiga yang dapat dirumuskan dari uraian di atas adalah:

$H_{3}$ : Mahasiswa akuntansi dengan tingkat love of money tinggi dan telah mendapat pendidikan kewirausahaan akan memiliki intensi yang lebih tinggi untuk berwirausaha dibandingkan dengan mahasiswa akuntansi dengan tingkat love of money rendah.

\section{Metode Penelitian}

\section{Populasi dan Sampel}

Populasi dalam penelitian ini adalah mahasiswa akuntansi di sebuah perguruan tinggi di Surakarta. Sampel yang digunakan dalam penelitian ini dibagi menjadi dua kategori, mahasiswa yang belum pernah mendapat pendidikan kewirausahaan dan mahasiswa yang telah menempuh mata kuliah kewirausahaan. Total sampel yang digunakan dalam penelitian ini sebanyak 70 mahasiswa aktif yang terbagi dalam dua kategori tersebut.

\section{Metode Pengumpulan Data}

Metode pengumpulan data yang digunakan dalam penelitian ini adalah dengan metode survei. Responden survei adalah mahasiswa yang telah menempuh mata kuliah kewirausahaan. Metode pengumpulan data dilakukan dengan cara membagikan kuesioner kepada responden yang memenuhi kualifikasi. Partisipan diminta untuk mengisi kuesioner dengan sejumlah pertanyaan. Sebelum mengisi kuesioner, mahasiswa diminta untuk membaca inform consent dan kesediaan mereka untuk menjadi partisipan dalam penelitian. Setelah membaca dan bersedia untuk menjadi partisipan diminta untuk menjawab pertanyaanpertanyaan singkat tentang variabel. Pada akhir sesi peserta di minta untuk mengisi data diri.

\section{Definisi Operasional dan Pengukuran}

Pendidikan kewirausahaan dalam penelitian ini digunakan sebagai variabel independen. Pendidikan kewirausahaan adalah suatu kegiatan pemberian edukasi terkait kewirausahaan kepada mahasiswa yang dilakukan di perguruan tinggi. Variabel dependen dalam penelitian ini adalah intensi untuk berwirausaaha. Intensi berwirausaha diukur dengan menjawab pertanyaan apakah responden memiliki niat untuk berwirausaha. Intensi responden untuk berwirausaha akan diukur menggunakan skala likert. Skala likert yang digunakan terdiri atas angka satu sampai dengan angka lima. Responden yang memilih angka satu maka akan dikategorikan tidak memiliki intensi untuk berwirausaha, hingga angka lima mengindikasikan bahwa responden memiliki intensi untuk berwirausaha yang tinggi.

Variabel lainnya adalah variabel love of money. Variabel love of money didefinisikan sebagai perilaku suatu sikap seseorang terhadap uang dengan afektif, komponen perilaku, dan aspirasi seseorang untuk uang (Law, 1998; Tang 2008). Skala Love of Money diadopsi dari skala yang digunakan oleh Tang, Sutarso, Davis, Dolinski, Ibrahim, dan Wagner (2007). Pengukuran mengunakan skala 1 hingga 4 dengan artian, (1) sangat setuju, (2) setuju, (3) tidak setuju, (4) sangat tidak setuju.

\section{Teknik Analisis Data}

Uji Validitas dan Uji Realibilitas digunakan pada penelitian ini. Penggunaan kedua pengujian tersebut ditujukan untuk melihat tingkat keabsahan dan keandalan suatu instrumen penelitian. Ketika instrumen tersebut memiliki tingkat keabsahaan dan keandalan yang tinggi maka instrumen dapat mengukur variabel yang telah diuji.

Teknik analisis data selanjutnya yang digunakan adalah analisis statistik deskriptif dan uji asumsi klasik. Pengujian hipotesis dalam penelitian ini menggunakan pendekatan analisis regresi linier dengan perangkat lunak olah data SPSS.Pengujian untuk hipotesis kedua menggunakan teknik $M R A$ (moderated Regression Analysis), dan menggunakan pengolah data SPSS.

\section{Hasil dan Pambahasan}

\section{Uji Validitas dan Uji Realibilitas}

Pengujian reliabilitas dan validitas instrumen dilakukan untuk menguji keandalan instrumen pada kuesioner. Pengujian reliabilitas pada penelitian ini dilakukan untuk menguji tingkat kepercyayaan indikator-indikator variabel untuk dapat mengukur variabel. Dari hasil uji realibilitas untuk variabel Love of Money didapatkan nilai cornbach alpha sebesar 0,816 (dari minimal 0,6) maka dapat disimpulkan bahwa instrumen penelitian yang digunakan untuk mengukur variabel LoM dapat dikatakan handal. Hasil pengujian validitas untuk variabel LoM menunjukkan bahwa semua $\mathrm{R}$ hitung lebih besar dari 0,3 maka instrumen valid untuk mengukur variabel. 


\section{Uji Asumsi Klasik}

Uji asumsi klasik juga dilakukan dalam penelitian ini. Hasil dari pengujian asumsi klasik menunjukkan bahwa pada uji normalitas didapatkan nilai signifikansi adalah 0,081 yang berarti di atas 0,05. Maka dapat dikatakan data berdistribusi normal. Uji Heteroskedastistisitas menunjukkan nilai 0,93 (LoM) dan 0,99 (PK), yang berarti nilai sig $>0,05$ maka tidak terjadi gejala heteroskedastisitas. Uji Multikolinieritas menunjukkan nilai tolerance 0,999 dan VIF 1,0001. Semua nilai tolerance lebih dari 0,10 dan nilai VIF kurang dari 10 , sehingga tidak ada korelasi antar variabel bebas, bebas dari multikolinnieritas. Hasil keseluruhan pengujian menunjukkan bahwa telah memenuhi asumsi klasik.

\section{Pengujian Hipotesis}

Pengujian hipotesis pertama menguji hubungan antara pendidikan akuntansi terhadap intensi untuk berwirausaha. Pengujian hipotesis ini menggunakan uji indpendent sample t-test untuk melihat perbedaan efek pada pemberian pendidikan kewirausahaan. Hasil pengujian hipotesis pertama menunjukkan nilai signifikansi sebesar 0,070 . Nilai signifikansi sebesar 0,070 yang berarti lebih besar dari 0,05, maka dapat diambil kesimpulan bahwa hipotesis pertama ditolak.

Pengujian hipotesis kedua menguji hubungan antara sikap kecintaan terhadap uang (LoM) terhadap intensi untuk berwirausaha. Hasil penngujian hipotesis kedua menunjukkan nilai signifikansi sebesar 0,015 . Nilai signifikansi sebesar 0,015 yang berarti kurang dari 0,05 , maka dapat diambil kesimpulan bahwa hipotesis kedua tidak dapat ditolak.

Pengujian hipotesis ketiga menguji hubungan antara pendidikan kewirausahaan terhadap intensi untuk berwirausaha yang dimoderasi oleh sikap kecintaan terhadap uang (LoM). Hasil penngujian hipotesis ketiga menunjukkan nilai signifikansi sebesar 0,756. Nilai signifikansi sebesar 0,756 yang berarti lebih dari 0,05, maka dapat diambil kesimpulan bahwa hipotesis ketiga dapat ditolak.

\section{Pembahasan}

Hasil dari pengujian menunjukkan bahwa pendidikan kewirausahaan belum memberikan efek yang cukup signfikan untuk meningkatkan intensi berwirausaha. Penelitian ini bertentangan dengan penelitian Zhao, Seibert, dan Hills (2005), Zhang, Duysters, dan Cloodt (2013), Ardiyani dan Kusuma (2016), Wedayanti dan Giantari (2016), Wibowo ak, 20(02), 2019, 262

(2017). Perlu diingat bahwa bentuk intensi untuk berwirausaha memiliki tingkatan yang lebih tinggi dibandingkan dengan minat untuk melakukan wirausaha. Ketika seseorang telah memiliki intensi untuk melakukan wirausaha, maka mereka akan selangkah lebih maju untuk mewujudkannya menjadi perilaku wirausaha.

Pendidikan kewirausahaan perlu disandingkan dengan variabel lain untuk dapat menunjang keefektifannya dalam meningkatkan intensi mahasiswa untuk berwirausaha. Penelitian yang dilakukan oleh Meinawati (2018), menunjukkan bahwa pendidikan kewirausahaan bersamaan dengan latar belakang keluarga memiliki efek positif yang signfikan terhadap efikasi diri kewirausahaan. Menawati (2018) beranggapan bahwa keluarga merupakan lingkungan yang pertama kali dikenal oleh anak, sehingga nilai-nilai kewirausahaan yang ditanamkan sejak dini dapat memupuk jiwa kewirausahaan dan semakin kuat ketika anak tersebut mendapatkan pendidikan kewirausahaan.

Penelitian Indiarti dan Rostiani (2008), menunjukkan temuan yang menarik pendidikan mahasiswa di Indonesia dengan latar belakang ekonomi dan bisnis tidak menunjukkan minat tinggi untuk menjadi wirausaha. Indarti dan Rostiani (2008) berpendapat bahwa hal tersebut menunjukkan kemungkinan bahwa kurikulum pendidikan ekonomi dan bisnis tidak diarahkan untuk menjadi wirausaha namun, cenderung dipersiapkan dan dibekali untuk bekerja di perusahaan-perusahaan berskala besar.

Pengujian hipotesis kedua menunjukkan bahwa sikap kecintaan terhadap uang (LoM) dapat mendorong intensi untuk berwirausaha. Temuan ini selaras dengan temuan Coleman pada tahun 1992, adanya uang akan menjadi ukuran atas segala sesuatu. Hal tersebut dikatakan dalam artikel Gagne dan Deci (2005) yang beranggapan bahwa mayoritas orang bekerja karena digerakkan oleh motivasi bernama uang. Setiawan dan Sukanti (2016), dalam penelitiannya menunjukkan bahwa ketika seseorang memiliki ekspetasi yang tinggi atas pendapatan maka akan berhubungan positif dengan minat untuk melakukan wirausaha. Kecintaan seseorang terhadap uang yang tinggi maka dapat mendorong seseorang untuk berwirausaha.

Hipotesis ketiga yang menyatakan hubungan antara pendidikan kewirausahaan terhadap intensi berwirusaha dengan dimoderasi tingkat Love of Money tidak dapat didukung. Hal tersebut mengindikasikan bahwa efektifitas pendidikan 


\section{Jurnal Akuntansi dan Pajak, 20(02), 2019, 263}

kewirausahaan untuk menimbulkan intensi berwirausaha perlu ditingkatkan dan dikemas agar dapat mencapai tujuan yang diinginkan. Pendidikan kewirausahaan berhubungan dengan entrepreneurial self-efficacy, hal tersebut akan meningkatkan intensi berwirausaha (Wilson, Kickul, dan Marlino, 2007; Zhao, Seiberr, dan Hills, 2005; dan Indarti dan Rostiani, 2008).

Pendidikan kewirausahaan harus mampu menciptakan kepercayaan diri mahasiswa untuk dapat berwirausaha. Ketika mahasiswa merasa dirinya mampu untuk melakukan wirausaha, maka mahasiswa akan lebih berani untuk berwirausaha, sehingga kegagalan-kegagalan tidak akan menghentikan mereka untuk berwirausaha. Bae, Qian, Miao, dan Fiet (2014), dalam studi meta analisis mereka menunjukkan dukungan atas kebijaksanaan konvensional bahwa hal kecil yang positif pada pendidikan kewirausahaan akan memberikan implikasi pada intensi untuk berwirausaha. Pendidikan kewirausahan seharusnya memberikan pembelajaran yang mendalam, meskipun hal tersebut dalam cakupan yang kecil. Hal tersebut akan lebih mengena terhadap sasaran dibandingkan dengan pembahasan yang melebar namun tidak memberikan hasil yang signifikan.

\section{Kesimpulan}

Penelitian ini menguji efektifitas pendidikan kewirausahaan terhadap intensi berwirausaha. Sikap kecintaan seseorang terhadap uang juga diuji dalam penelitian ini. Adanya penelitian ini dilatar belakangi oleh agenda peningkatan jumlah pelaku wirausaha. Pelaku wirausaha perlu ditingkatkan karena hal tersebut akan menjadi penopang perekonomian suatu negara dengan kontribusi yang besar.

Penelitian ini menggunakan mahasiswa akuntansi sebagai obyek penelitian. Hal tersebut dikarenakan mahasiswa akuntansi dikenal sebagai subyek yang sensitif dengan uang. Mahasiswa akuntansi sangat memahami nilai materiil dari uang. Variabel kecintaan terhadap uang ini, dirasa akan memberikan peran tersendiri bagi mahasiswa akuntansi untuk dapat mendorong intensi mereka untuk berwirausaha. Penelitian ini berhasil menunjukkan bahwa tingkat kecintaan seseorang terhadap uang yang tinggi mampu menimbulkan intensi untuk berwiarusaha.

Pendidikan kewirausahaan perlu dikemas dengan kurikulum yang mampu memberikan efektifitas yang signifikan untuk mendorong mahasiswa memiliki intensi berwirausaha. Pengemasan kurikulum ini perlu mendapat perhatian khusus bagi penyelenggara pendidikan. Hal tersebut bertujuan agar langkah yang ditempuh dapat mencapai tujuan yang diharapkan.

\section{Implikasi Penelitian}

Penelitian ini memberikan implikasi teoritik, bahwa variabel Love of Money berhubungan dengan intensi mahasiswa untuk mendorong intensi berwirausaha mahasiswa. Implikasi praktis yang dapat dihasilkan dari penelitian ini adalah pendidikan kewirausahaan ternyata mata kuliah yang memerlukan perhatian khusus apabila ingin mendukung agenda nasional. Kurikulum pendidikan kewirausahan harus dikemas untuk mampu menmbuhkan intensi mahasiswa dalam berwirausaha.

\section{Keterbatasan dan Saran Penelitian}

Keterbatasan penelitian ini adalah hanya mampu menangkap kondisi pada satu waktu tertentu saja. Akan lebih baik bila penelitian dilakukan dengan metode eksperimen sehingga efek dari pendidikan kewirausahaan dapat jelas terlihat. Pada penelitian ini hanya menguji efektifitas kurikulum dalam pendidikan kewirausahan tempat sampel menempuh pendidikan. Kurikulum yang tidak berubah tersebut tidak berubah sehingga dipandang layak untuk dijadikan obyek observasi.

Saran untuk penelitian di masa mendatang, penelitian dapat menggunakan metode eksperimen dengan variabel kurikulum pendidikan kewirausahaan. Hasil tesebut akan dapat terlihat kurikulum pendidikan kewirausahaan yang seperti apa yang paling efektif meningkatkan intensi mahasiswa dalam berwirausaha. Penelitian di masa depan dapat menggunakan variabel kecintaan terhadap uang di penelitian mendatang dengan memadu padankan dengan variabel lain seperti latar belakang keluarga untuk dapat melihat efek simultan pada intensi berwirausaha.

\section{Daftar Pustaka}

Acs, Z. (2006). How is entrepreneurship good for economic growth?. Innovations: technology, governance, globalization, 1(1), 97-107.

Amit, R., Mac Crimmon, K. R., Zietsma, C., \& Oesch, J. M. (2001). Does money matter?: Wealth attainment as the motive for initiating growth-oriented technology ventures. Journal of business venturing, 16(2), 119-143. 


\section{Jurnal Akuntansi dan Pajak, 20(02), 2019, 264}

Ardiyani, N. P. P., \& Kusuma, A. A. A. (2016). Pengaruh sikap, pendidikan dan lingkungan keluarga terhadap minat berwirausaha. E-Jurnal Manajemen, 5(8).

Bae, T. J., Qian, S., Miao, C., \& Fiet, J. O. (2014). The relationship between entrepreneurship education and entrepreneurial intentions: A meta-analytic review. Entrepreneurship theory and practice, 38(2), 217-254.

Bonner, S.E. dan Sprinkle, G.B., (2002). "The Effects of Monetary Incentives on Effort and Task Performance: Theories, Evidence, And A Framework for Research.” Accounting, Organizations and Society, 27(4), pp.303-345.

Brandstätter, E., \& Brandstätter, H. (1996). What's money worth? Determinants of the subjective value of money. Journal of Economic Psychology, 17(4), 443-464.

Cassar, G. (2007). Money, money, money? A longitudinal investigation of entrepreneur career reasons, growth preferences and achieved growth. Entrepreneurship and Regional Development, 19(1), 89-107.

Coleman, J. W. (1992). Crime and money: motivation and opportunity in a monetarized economy. American Behavioral Scientist, 35(6), 827-836.

Corman, J., Perles, B., \& Yancini, P. (1988). Motivational factors influencing hightechnology entrepreneurship. Journal of Small Business Management, 26(1), 36.

Donckels, R. (1991). Education and entrepreneurship experiences from secondary and university education in Belgium. Journal of Small Business and Entrepreneurship, 9(1), 3542.

Gagné, M. dan Deci, E.L., 2005. "SelfDetermination Theory and Work Motivation." Journal of Organizational behavior, 26(4), pp.331-362.

Germak, A. J., \& Robinson, J. A. (2014). Exploring the motivation of nascent social entrepreneurs. Journal of Social Entrepreneurship, 5(1), 5-21.

Ghozali, Imam. (2015). Partial Least Square: Konsep, Teknik, dan Aplikasi. Semarang: Badan Penerbit UNDIP

Indarti, N., \& Rostiani, R. (2008). Intensi kewirausahaan mahasiswa: Studi perbandingan antara Indonesia, Jepang dan Norwegia. Journal of Indonesian Economy and Business, 23(4), 369-384.
Law, K. S., Wong, C. S., \& Mobley, W. M. (1998). Toward a taxonomy of multidimensional constructs. Academy of management review, 23(4), 741-755.

Lestari, R. B., \& Wijaya, T. (2012). Pengaruh Penddidikan Kewirausahaan terhadap Minat Berwirausaha Mahasiswa di STIE MDP, STMIK, dan STIE Musi. Forum Bisnis dan Kewirausahaan Jurnal Ilmiah STIE MDP, (Vol. 1 No. 2, pp. 112-119)

Liñán, F., Rodríguez-Cohard, J. C., \& RuedaCantuche, J. M. (2011). Factors affecting entrepreneurial intention levels: a role for education. International entrepreneurship and management Journal, 7(2), 195-218.

Li-Ping Tang, T., Shin-Hsiung Tang, D., \& LunaArocas, R. (2005). Money profiles: The love of money, attitudes, and needs. Personnel review, 34(5), 603-618.

Li-Ping Tang, T., Chen, Y. J., \& Sutarso, T. (2008). Bad apples in bad (business) barrels: The love of money, Machiavellianism, risk tolerance, and unethical behavior. Management Decision, 46(2), 243-263.

Liu, B. C., \& Tang, T. L. P. (2011). Does the love of money moderate the relationship between public service motivation and job satisfaction? The case of Chinese professionals in the public sector. Public Administration Review,71(5), 718-727.

Meinawati, N. (2017). Pengaruh Latar Belakang Keluarga dan Pendidikan Kewirausahaan terhadap Intensi Berwirausaha melalui Efikasi Diri. Indonesian Journal of Economic Education(IJEE), 1(1).

Morton, F. M. S, \& Podolny, J. M. (2002). Love or money? The effects of owner motivation in the California wine industry. The Journal of Industrial Economics, 50(4), 431-456.

Noersasongko, E. KEWIRAUSAHAAN: Perubahan Zaman: Ilmu Kosong tetapi Berisi. Penerbit Andi.

Robbins, S.P. dan Judge, T. A., 2015. Organizational Behavior, $16^{\text {th }}$ Edition. Pearson

Scott-Clayton, J. (2011). On money and motivation a quasi-experimental analysis of financial incentives for college achievement. Journal of Human resources, 46(3), 614-646.

Scott Morton, F. M., \& Podolny, J. M. (2002). Love or money? The effects of owner motivation in the California wine industry. The Journal of Industrial Economics, 50(4), 431-456. 


\section{Jurnal Akuntansi dan Pajak, 20(02), 2019, 265}

Setiawan, D., \& Sukanti, S. (2016). Pengaruh Ekspektasi Pendapatan, Lingkungan Keluarga dan Pendidikan Kewirausahaan Terhadap Minat Berwirausaha. Jurnal Profita: Kajian Ilmu Akuntansi, 4(7).

Tang, T. L. P. (1992). The meaning of money revisited. journal of Organizational Behavior, 13(2), 197-202.

Tang, T. L. P., \& Kim, J. K. (1999). The meaning of money among mental health workers: The endorsement of money ethic as related to organizational citizenship behavior, job satisfaction, and commitment. Public Personnel Management, 28(1), 15-26

Tang, T. L. P. (2007). Income and quality of life: Does the love of money make a difference?. Journal of Business Ethics, 72(4), 375-393.

Tang, T. L. P., Sutarso, T., Davis, G. M. T. W., Dolinski, D., Ibrahim, A. H. S., \& Wagner, S. L. (2008). To help or not to help? The Good Samaritan Effect and the love of money on helping behavior. Journal of Business Ethics, 82(4), 865-887.

Vitell, S. J., Paolillo, J. G., \& Singh, J. J. (2006). The role of money and religiosity in determining consumers' ethical beliefs. Journal of business ethics, 64(2), 117-124.

Wedayanti, N. P. A. A., \& Giantari, I. G. A. K. (2016). Peran pendidikan kewirausahaan dalam memediasi pengaruh norma subyektif terhadap niat berwirausaha. E-Jurnal Manajemen, 5(1).
Wennekers, S., \& Thurik, R. (1999). Linking entrepreneurship and economic growth. Small business economics, 13(1), 27-56.

Wibowo, A. (2017). Dampak pendidikan kewirausahaan bagi mahasiswa. Asian Journal of Entrepreneurship and Family Business, 1(1), $1-14$.

Wilson, F., Kickul, J., \& Marlino, D. (2007). Gender, entrepreneurial self-efficacy, and entrepreneurial career intentions: Implications for entrepreneurship education. Entrepreneurship theory and practice, 31(3), 387-406.

Zhang, Y., Duysters, G., \& Cloodt, M. (2014). The role of entrepreneurship education as a predictor of university students' entrepreneurial intention. International entrepreneurship and management journal, 10(3), 623-641.

Zhao, H., Seibert, S. E., \& Hills, G. E. (2005). The mediating role of self-efficacy in the development of entrepreneurial intentions. Journal of Applied Psychology, 90(6), 12651272.

\section{Sumber Lain:}

Kompas, 5 April 2018: Jumlah entrepreneur di Indonesia Jauh di Bawah Negara Maju ini kata Jokowi.

Laporan Perkembangan Data Usaha Mikro, Kecil, Menengah (UMKM) dan Usaha Besar (UB) TAHUN 2016 - 2017 (Kementerian Koperasi dan UKM)

http://www.depkop.go.id/uploads/laporan/15499467 78_UMKM\%202016-2017\%20rev.pdf 